\title{
The Socio-Political History of China's Three Gorges Dam
}

\author{
Caitlynn Beckett*
}

\begin{abstract}
Around the world, the construction of large-scale dams has become a controversial environmental issue. A significant example of such a dam is the Three Gorges Dam on the Yangtze River in China. The Yangtze River, considered the cradle of Chinese civilization, has fundamentally shaped Chinese livelihood, culture, transportation, and agriculture. Despite international and local dissent, as of 2012, the Three Gorges Dam has become a reality. Having fundamentally altered the river system, the biodiversity of the area is now threatened by flooded habitats upstream, drought downstream and a change in nutrient distribution. However, to better understand the reasoning behind the construction of the Three Gorges Dam, a deeper historical, cultural and political basis needs to be recognized. This paper will investigate how the specific history of China has led to the construction of the Dam. Throughout the $20^{\text {th }}$ century, political leaders envisioned the Dam as a symbol of Chinese industrialization and modernization. Ironically, it was considered the ultimate achievement in China's development. Communist views of mastery over nature played an important role in such political views. These views are not limited to China; the idea that humans should control nature for economic benefit is still evident throughout the world. Beyond the context of China, the Three Gorges Dam is a symbol of the larger systems that value economic benefit and industrialization over a sustainable environment.
\end{abstract}

Keywords: Three Gorges Dam, Yangtze River, China, environmental history, Mao, hydropower

The Yangtze River is the longest river in China and the third longest river in the world. The eastern reaches of this river have been considered the cradle of Chinese civilization since 8000 B.C.E. ${ }^{1}$ Historically, the Yangtze River has been a

\footnotetext{
${ }^{1}$ Stuart A. Harris, "Environmental and Land-use Changes in the Tibetan Plateau Section of the Upper Yangtze River Basin during the Last 50 Years," in Yangtze River: Geography, Pollution and Environmental Implications, ed. Tracy Maloney and Boyce R. Hutchins (New York: Nova Science Publishers, Inc., 2013), 36.
}

\footnotetext{
*Department of International Studies, College of Arts and Science, University of Saskatchewan, Saskatoon, SK, Canada Correspondence: caitlynn.beckett@sasktel.net 
fundamental aspect of life for many Chinese people. The vast expanse of this river, along with its many tributaries, has been essential for Chinese livelihood and culture and is important for transportation and connections between the coastal areas and the interior. Today, the Yangtze River is an important source of electricity and it continues to be an important aspect of transportation, trade, industry and agriculture. ${ }^{2}$ Over the past century, industrialization has led to extensive negative environmental consequences throughout the Yangtze River area. A good example of such industrialization is the Three Gorges Dam. The Three Gorges Dam was originally envisioned as early as $1919,{ }^{3}$ but the building process has been long, fragmented, and heavily influenced by historical, political, and societal circumstances such as communism and the international economy. Today, many consider the Dam to be an environmental and social failure. The Chinese government continues to see the Three Gorges Dam as an essential part of their plan for economic growth and an increased standard of living. ${ }^{4}$

Despite multiple obstacles and public dissent, as of 2012 the Three Gorges Dam has become a reality. The biodiversity of the area is threatened as the dam floods habitats upstream, drought wreaks havoc downstream, and millions of people are displaced, to name only a few of the failures of the Dam. ${ }^{5}$ And yet, undeterred by predicted problems such as flooding and habitat destruction, the

\footnotetext{
${ }^{2}$ Kepa Morgan and Amaria Francis Waretini, "The Yangtze River: Hydro Development, Changing Geography, Cultural and Environmental Implications," in Yangtze River: Geography, Pollution and Environmental Implications, ed. Tracy Maloney and Boyce R. Hutchins (New York: Nova Science Publishers, Inc., 2013), 66.
}

${ }^{3}$ Sun Yat-sen, The International Development of China, (Shanghai: Commercial Press Limited, 1922), page number.

${ }^{4}$ Chinese Government's Official Web Portal, "Special Report: Three Gorges Project," 2012, accessed 10 March 2014, http://english.gov.cn/special/sanxia_index.htm.

\footnotetext{
${ }^{5}$ Mara Hvistendahl, "China's Three Gorges Dam: An Environmental Catastrophe?" Scientific American, 25 March 2008, http://www.scientificamerican.com/article/chinas-threegorges-dam-disaster/.
}

Chinese government approved construction. ${ }^{6}$ To better understand the reasoning behind the Dam, this paper will place the idea to build the Three Gorges Dam in a historical context before focusing on environmental manipulation. From here, the paper will focus on the ideology and politics of Chairman Mao and how ideas behind campaigns such as 'The Great Leap Forward' have contributed to the environmental degradation of China. This helps to provide a deeper cultural and political basis to better understand the construction of the Dam. The paper will then look briefly at possible reasons behind the final decision to build the Dam. The Three Gorges Dam project is a reflection of the broader political, historical, and social situation in China. This project did not simply materialize out of a need for hydropower, but rather is the result of a complex historical context. Industrialization, modernization, communism, and the concept of economic development have all contributed to the Dam's construction. Although this paper identifies the environmental degradation caused by decisions made by the Chinese government, it is important to note that such decisions are not limited to the Chinese government. International pressure to modernize, industrialize, and contribute to an international economy dominated by Western ideals of progress shaped development decisions in China. ${ }^{7}$ The Three Gorges Dam, beyond the Chinese context, can be seen as a symbol of a much broader drive for modernization and the environmental and social issues affecting people worldwide.

Despite the relatively recent abundance of negative press surrounding the Three Gorges Dam and other dams in China ${ }^{8}$ the Chinese have successfully practiced forms of hydrological manipulation for thousands of years. For example, the Dujiangyan Dam system, built in 256 B.C.E., was constructed for flood control and irrigation and remains

\footnotetext{
6 Peter H. Gleick. "Three Gorges Dam Project Yangtze River, China," in The World's Water 2008-2009: The Biennial Report on Freshwater Resources, ed. Peter $\mathrm{H}$. Gleick, (Washington: IslandPress, 2009), 141.

7 Philip M Fearnside, “China's Three Gorges Dam: 'Fatal' Project or Step Towards Modernization?" World Development 16 (1988): 615-630.

${ }^{8}$ Examples of such negative press can be seen throughout newspapers and documentaries such as Up the Yangtze, National Film Board of Canada (Montreal: Eyesteel Film, 2007).
} 
functional to this day. ${ }^{9}$ Thus, the Chinese have an "extensive historic association with hydraulic technologies." ${ }^{10}$ The ability to manage water systems has been an essential aspect of Chinese culture, agriculture and politics throughout history and has been an important part of the imperial control exercised by Chinese empires. However, as Marks argues, many of these hydrological changes began to cause problems by the end of the eighteenth century. Deforestation and diking resulted in increased siltation, flooding, and the loss of nutrients, which was detrimental to local residents. ${ }^{11}$ In addition to this, Marks argues that population growth and "competition for increasingly scarce resources on both land and water occasioned more and increasingly sharp social conflict. ${ }^{12}$ This conflict contributed to the fall of the Qing Dynasty. ${ }^{13}$ In this context, whereas the social and political contexts shape decisions about the environment, the environment also shapes society and politics.

It is important to recognize these social and political connections when investigating the Three Gorges Dam. Such a project reflects not only the opinion of those in power and a history of imperial control, but also the fact that the Chinese have historically grappled with devastating floods and environmental obstacles, which have shaped their society and politics today. However, the various Chinese governments throughout the past century have seemed unwilling to acknowledge that such devastating floods are arguably the result of past deforestation and other environmental changes. ${ }^{14}$ Rather than addressing these environmental problems, the Yat-sen, Mao and Xiaoping governments have focused on industrialization and economic development and have justified their decisions by highlighting the benefits and prestige of environmental control and economic gain within an

\footnotetext{
9 Morgan and Waretini, “The Yangtze River," 67.

10 lbid.,
}

11 Robert B. Marks, China: Its Environment and History (Maryland: Rowman and Littlefield Publishers, 2012), 244, 263.

12 Ibid., 263.

13 Ibid.,

14 Ibid., 265. international market. Such economic and developmentbased decisions are not limited to the Chinese context and reflect international influences such as Soviet relations, the Cold War and, more recently, an increasingly neoliberal, market-based economy. It is therefore important to recognize the role that international politics and economic relations with countries such as United States played in hydrological development in China throughout the late $20^{\text {th }}$ century. ${ }^{15}$

Despite an impressive background of hydraulic works and irrigation systems, dam construction was relatively discrete before $1949 .{ }^{16}$ After the Chinese Civil War and the establishment of the People's Republic of China in 1949, the construction of large dams became an important aspect of policies intended to bring about fast economic growth and industrialization. ${ }^{17}$ However, the original ideas for grand projects such as the Three Gorges Dam are found in earlier roots, when Chinese nationalists sought to break away from dynastic rule and Western imperial control. As early as 1919, Sun Yat-Sen, 'the father of modern China, ${ }^{18}$ wrote an article entitled, A Plan to Develop Industry, in which he mentioned the possibility of building a series of dams along the Yangtze River in order to control flooding and develop an extensive system of electricity generation. ${ }^{19}$ In a comprehensive report published in 1922 entitled, The International Development of China, Sun Yat-sen outlined the Chinese government's plan for industrial development. Included in this document is an entire chapter entitled "The

${ }^{15}$ Yuen-Ching Bellette Lee, "Global Capital, National Development and Transnational Environmental Activism: Conflict and the Three Gorges Dam," Journal of Contemporary Asia 43, no.1 (2013): 106.

${ }^{16}$ Marta Ponseti and Jordi Lopez-Pujol, "The Three Gorges Dam Project in China: History and Consequences," Revista HMiC: Historia Moderna I Contemporania 4 (2006): 152.

${ }^{17}$ Ponseti and Lopez-Pujol, "The Three Gorges Dam Project in China," 152.

${ }^{18}$ Sun Yat-sen was a Chinese revolutionary and the first president of the Republic of China. See Morgan and Waretini, "The Yangtze River," 68.

${ }^{19}$ Ponseti and Lopez-Pujol, "The Three Gorges Dam Project in China," 153. 
Regulation of the Yangtze River. ${ }^{\prime 20}$ Most important, he also situated China within an international context of industrialization: "As a late comer, China can greatly profit in covering the space by following the direction already charted by Western pioneers." ${ }^{21}$ Yat-sen's approach was intended to modernize China according to Western standards. The international community supported this type of industrial progress and, specifically, the Three Gorges Dam itself. Yat-sen includes in his writings letters from various government officials, who state that the economic development of China will be beneficial to all mankind, and that development should occur in order to "exploit the great hidden riches of China." ${ }^{22}$ The influence of international economic forces becomes obvious in such circumstances. It also becomes impossible to simply blame the Chinese government for environmental degradation, since it is obviously a much broader, historic problem.

In the context of past imperial control, visions of Chinese nationalism and the recent World War, Yat-sen recognizes that "The Chinese people at last are waking up and realizing that [they] must get up and follow in the world's progress." ${ }^{23}$ In this sense, the grand scale of development at any cost can be seen as a method to overcome impoverishment and embrace progress. There seems to be a sense in this report that the Chinese government of the time feels the need to catch up with the modernizing world and to overcome backwardness. ${ }^{24}$ Although Sun Yat-sen's nationalist party failed, resulting in civil war and the eventual take over by the Communist Party in 1949, this push to overcome backwardness was carried through in Communist policies. According to Meisner, this backwardness is "both social and economic the historical legacy of a century of the failure of both

${ }^{20}$ Yat-sen, The International Development of China, 164.

21 lbid.,

22 Letter from General Caviglia, Il Ministro Della Guerra, Rome, May 171919 quoted in Yat-sen, The International Development of China, 259.

${ }^{23}$ Yat-sen, The International Development of China, 161.

${ }^{24}$ Ibid., 21. reform and revolution. ${ }^{\prime 25}$ Overcoming impoverishment has been central in determining Chinese social development in the past century. Development and economic progress were to be brought about through the mastery of nature. However, this approach, in turn, caused environmental degradation, which has continued to pose challenges to Chinese society. ${ }^{26}$

Yat-sen's proposals to build the Three Gorges Dam were disrupted during the Chinese Civil War. However, plans once again surfaced after floods along the Yangtze in 1954 caused over 30000 deaths. ${ }^{27}$ Although socialist roots can be seen in Yat-sen's work when he states that he intends to "make all the national industries of China into a Great Trust owned by the Chinese people, ${ }^{\prime 28}$ the new communist government extensively expanded these industries. Despite strong opposition from Chinese intellectuals during the Hundred Flowers Movement in 1956 , ${ }^{29}$ the Central Committee of the Chinese Communist Party approved the construction of the Three Gorges Dam in 1957. Embedded within Chinese Communist policies for rapid industrial development were ideas derived from Marx, Lenin, China's imperial legacy, Soviet Communism, and Western science. Although these are all different views, Marks argues that they all share the modernist disposition

${ }^{25}$ Maurice Meisner, Mao's China and After: A History of the People's Republic (New York: The Free Press, 1999), 58.

${ }^{26}$ Robert B. Marks, "Chinese Communists and the Environment," in Radicalism, Revolution and Reform in Modern China, ed. Catherine Lynch, Robert B. Marks, and Paul G. Pickowicz (Maryland: The Rowman and Littlefield Publishing Group Inc., 2011), 106.

27 Ponseti and Lopez-Pujol, "The Three Gorges Dam Project in China," 153.

${ }^{28}$ Yat-sen, The International Development of China, 164.

${ }^{29}$ The Hundred Flowers Movement was a campaign launched in 1956 aimed at encouraging Chinese intellectuals to discuss the country's problems and to promote science and culture. However, this campaign was short lived since many intellectuals began to call for the Communist Party to leave power. In reaction, Mao started an 'anti-rightest' campaign targeting those who opposed the government. See Ponseti and Lopez-Pujol, "The Three Gorges Dam Project in China,". 
that humans were separate from nature, that resources should be used to support humans, and that people should dominate nature. ${ }^{30}$

Many scholars have made the connection between Marxist theories of the relationship between humans and nature and Chairman Mao's beliefs. The most obvious connection can be seen in Marx's view of the position of nature in a capitalist society; he saw "Nature's forces ... as productive forces [that] slumbered in the lap of social labour. ${ }^{\prime \prime 1}$ However, Mao takes this one step further and uses approaches to nature that were influenced more by Lenin's Soviet visions of large-scale industrialization than Marx's views of production. Lysenko, a Soviet biologist, dismissed Western, bourgeois biology because it merely sought to understand nature, whereas the aim of communism was to change nature in pursuit of industrialization. ${ }^{32}$ While being influenced by this view, Mao's communism also relied on the modernist view of science as a tool to control nature. In this sense, modernity was to be achieved through the domination of nature. Mao saw nature and society as "objects of change and control; ... both could be altered and directed from the outside, as it were, by reshaping environments. ${ }^{133}$ Control of the environment became an inherent aspect of social revolution and social control. The best way to highlight this control was through the execution of large-scale projects such as the Three Gorges Dam.

The following excerpt from a poem written by Mao exhibits his feelings, and more generally, the Chinese government's attitudes towards the Three Gorges Project:

And now I am swimming across the great Yangtze...

A bridge will fly to span the north and south, turning a deep chasm into a thoroughfare.

Walls of stone will stand upstream to the west to hold back,

${ }^{30}$ Marks, China, 271.

${ }^{31}$ Karl Marx and Friedrich Engels, The Manifesto of the Communist Party, accessed on 18 March 2014, https://www.marxists.org/archive/marx/works/1848/com munist-manifesto/.

32 Marks, China, 272.

${ }^{33}$ Laurence Schneider, Biology and Revolution in

Twentieth-Century China (Maryland: The Rowman and Littlefield Groups Publishers Inc., 2003), 272.
Wushan's clouds and rain till a smooth lake rises in the narrow gorges.

The Mountain Goddess if she is still there

will marvel at a world so changed. ${ }^{34}$

This excerpt from Mao's poem exhibits a triumph over adversity. In such terms, the construction of the Three Gorges Dam would be seen as a great achievement for the Chinese people. As mentioned above, the Yangtze River has been a mixed blessing for the Chinese people. The use of technology and industry to control and harness such a force could be seen as a great success, not only in Chinese society, but also throughout many societies worldwide. However, the rapid increase in both the number and size of dams built after the establishment of the People's Republic of China suggests that the Mao government specifically saw dams as an important aspect of a greater social and economic control, in addition to a source of power. ${ }^{35}$ According to Shui Fu, the Chinese Communist Party associated dams with the development of the country: "Harnessing rivers became equated with harnessing people. ${ }^{.136}$

The approach of harnessing and controlling rivers can be seen in what Murphey sees as a "war against nature, ${ }^{137}$ or more specifically as Shapiro terms it, "Mao's war against nature. ${ }^{\prime \prime 38}$ Dams became an important aspect of this war for fast economic development. The Great Leap Forward was an ambitious, ideologically based governmental plan aimed

${ }^{34}$ Mao Zedong, Swimming, June 1956, retrieved from Selected Works of Mao Tse-tung, http://www.marxists.org/reference/archive/mao/selectedworks/poems/poems23.htm.

35 Ponseti and Lopez-Pujol, "The Three Gorges Dam Project in China," 152-153.

${ }^{36}$ Shui Fu, "A Profile of Dams in China," in The River Dragon Has Come: The Three Gorges Dam and The Fate of China's Yangtze River and Its People, ed. Dai Qing, trans. Yi Ming (New York: M.E. Sharpe, Inc., 1998), 19.

${ }^{37}$ Rhoads Murphy, "Man and Nature in China," Modern Asian Studies 1 (1967): 333.

${ }^{38}$ Judith Shapiro, Mao's War Against Nature: Politics and the Environment in Revolutionary China (United Kingdom: Cambridge University Press, 2001). 
at transforming China from an agrarian society into a productive paradise. In this sense, Mao differs from Marx and Lenin in that he saw revolution as a peasant-based rather than proletariat-based process. ${ }^{39}$ The Great Leap Forward included plans for fast paced campaigns to construct new irrigation networks, increase iron and steel production, and eliminate pests. Such campaigns resulted in massive environmental degradation and eventually led to a famine that caused the death of up to 30 million people by 1960. This war against nature ultimately backfired, resulting in environmental destruction, agricultural decline, and famine. In the context of the Great Leap Forward, the Dam was envisioned as a symbol of the peasant's revolutionary potential and would have been the ultimate beacon of a successful communist revolution. However, the instability caused by the famine led the Chinese government to abandon construction plans for the Three Gorges Dam. ${ }^{40}$ The failure of plans for the Three Gorges Dam at this time was reflective of the failure of Mao's plan for a peasant revolution.

Plans for construction once again surfaced in the late 196os. Murphey cites multiple titles in the popular press of China during this time, including: "We Bend Nature to Our Will," "Chairman Mao's Thoughts are Our Guide to Scoring Victories in the Struggle Against Nature," and "The United Will of the People Can Conquer Nature. ${ }^{\prime 41}$ These headlines are obviously created by a state controlled media; the voices of those who disagreed with projects such as the Three Gorges Dam were silenced. After the failure of The Great Leap Forward, Mao sought to consolidate his power by enforcing strict communism, resulting in the Cultural Revolution from 1966 to1976. ${ }^{42}$ During this revolution, Mao's mistrust of intellectuals and reluctance to listen to differing opinions led to many professionals being labeled

${ }^{39}$ Franz Schurmann, Ideology and Organization in Communist China, (California: University of California Press, 1966), 309.

40 Ponseti and Lopez-Pujol, “The Three Gorges Dam Project in China," 153.

${ }^{41}$ Murphy, "Man and Nature in China," 319.

42 Dai Qing, "The Three Gorges Project," in The River Dragon Has Come: The Three Gorges Dam and The Fate of China's Yangtze River and Its People, ed. Dai Qing, trans. Yi Ming (New York: M.E. Sharpe, Inc., 1998), 8. as "rightests". Those who strongly opposed the Three Gorges Dam, such as the engineer Huang Wanli, were excluded from professional life and even sent to labour camps. ${ }^{43}$ In Maoist China, according to Shapiro, "lack of freedom of speech and of intellectual inquiry had grave consequences for the human relationship with nature." ${ }^{44}$ The only view accepted was one of industrialization and development at any cost. As mentioned above, this cost ended up being extreme environmental degradation and the loss of up to 30 million lives. With a silenced opposition, plans for the Dam were allowed to proceed.

There is an important transition from Maoist China to the government of Deng Xiaoping and the economic reforms that Xiaoping introduced in 1979. Since these economic reforms, the growth of the Chinese economy has helped to pull millions out of poverty. However, this rapid growth has severely affected China's environment and has caused social displacement across the country, as is highlighted in the case of the Three Gorges Dam. ${ }^{45}$ Although the influence of Chinese socialism continued to shape the planned construction of the Three Gorges Dam, Xiaoping policies were largely seen as a response to the failure of Mao's economic policies and represent a large shift towards capitalism and a market economy..$^{46}$ In this context, Xiaoping emphasized that the Three Gorges Dam was needed to be able to produce more electric power in order to encourage economic growth. However, waves of domestic and international protests and various contradictory reports regarding feasibility continually pushed back the implementation of plans for the Dam. ${ }^{47}$ Finally, in 1990, Li Peng, a Soviet educated engineer and the Prime Minister of China between 1988 and 1998, campaigned for a revival of the project. In a statement that echoed the ideas of Sun Yat-sen and Mao, Li Peng stated

${ }^{43}$ Shapiro, Mao's War Against Nature, 23

44 Ibid., 24

45 Joseph Kahn and Jim Yardley, "As China Roars, Pollution Reaches Deadly Extremes," The New York Times, 26 Aug 2007.

${ }^{46}$ Bellette Lee, “Global Capital, National Development and Transnational Environmental Activism,"103.

47 Ponseti and Lopez-Pujol, "The Three Gorges Dam Project in China," 153-156. 
that the damming of the Yangtze "is an event that not only inspires people but demonstrates the greatness of the achievement of China's development. ${ }^{148}$ In this statement, it is important to identify that the Three Gorges Dam project, throughout a century of planning, has become connected to Chinese nationalism and ethno-centrism in the eyes of the government. ${ }^{49}$ According to Sullivan, there is a common Chinese saying that "Only China can save socialism. ${ }^{\prime 50}$ Sullivan then states that the Three Gorges Dam, as a symbol of the might of Chinese Communism, may be intended, in part, as "political C.P.R." ${ }^{11}$

Devastating floods occurred in 1991, killing about 3000 people. These floods became a crucial factor for supporters of the Dam to attain approval for the project. Supporters emphasized the urgent need of infrastructure in order to prevent such floods from occurring in the future..$^{52}$ This resurgence of interest during floods is an interesting trend throughout the history of plans for the Three Gorges Dam. Other calls for dam construction, such as economic development or energy production, have not gathered as much support. In April 1992, the Chinese government approved a resolution to construct the Three Gorges Dam. However, this resolution barely had enough votes to pass, which is uncommon, suggesting the very controversial nature of this project. ${ }^{53}$

${ }^{48}$ Antoaneta Bezlova, “China's Three Gorges Dam Comes of Age," Asian Times, 4 November 2009, accessed 18 March 2014, http://www.atimes.com/atimes/China/KK04Ad01.html.

${ }^{49}$ Lawrence B Sullivan, "The Three Gorges Dam and the Chinese Polity," preface to Yangtze!Yangtze by Dai Qing, ed. Patricia Adams and John Thibodeau. trans. Nancy Liu et al. (London: Probe International Earthscan, 1994), accessed 18 March 2014, http://journal.probeinternational.org/three-gorgesprobe/yangtze-yangtze/.

${ }^{50}$ Ibid., ${ }^{51}$ Ibid.,

52 Ponseti and Lopez-Pujol, "The Three Gorges Dam Project in China," 156.

${ }^{53}$ Ibid.,
As the Dam has been constructed over the past two decades, there has been increasing attention placed on the environmental impacts of development. In the case of the Three Gorges Dam, Morgan and Waretini suggest that a form of cost-benefit analysis has been adopted "to evaluate the monetary value of environmental protection measures and economic benefits. ${ }^{154}$ In this economic sense, China has been as concerned about achieving economic development, as most other countries in this time period. In addition, according to Lee, there has been an increased rhetoric around hydropower as the answer for a sustainable power source in China. ${ }^{55}$ Large dams in China and around the world are being promoted as green energy sources. The Three Gorges Dam was designed to control flooding, improve navigation, generate electricity and provide water storage for irrigation. These can all be seen as very beneficial to Chinese economy and society. However, the Dam has in fact flooded habitats, caused drought, slowed navigation, caused extensive migration, and has not produced as much energy as was predicted..$^{56}$ Perhaps the criticism of this one project reflects a broader, more historical criticism of a system that measures benefits through economic returns. Economic returns are easier to quantify and are more tangible. The "Golden Waterway" described in Captain William Gill's, The River of Golden Sand ${ }_{1}^{57}$ is now seen as a strategic asset, like so many other natural resources worldwide.

Besides being portrayed as a positive symbol of modernization and economic development, the Dam, to many Chinese, has also been a negative symbol of state control. In the push for economic and political gain, many poor, local people have been further marginalized and forced to move. By the time the project was completed, 1.25 million people had been displaced, the majority of

\footnotetext{
${ }^{54}$ Morgan and Waretini, "The Yangtze River," 68.

${ }^{55}$ Bellette Lee, "Global Capital, National Development and Transnational Environmental Activism," 117.
}

${ }^{56}$ Mara Hvistendahl, "China’s Three Gorges Dam: An Environmental Catastrophe?"

${ }^{57}$ William Gill, The River of Golden Sand: The Narrative of a Journey Through China and Eastern Tibet to Burmah (London: John Murray Publishers, 1880). 
these people being rural. $^{58}$ Not only are there many critiques of the government's plan to move so many people, but also, the majority of the displaced people are rural farmers, meaning that they rely on their land for a livelihood. Therefore, the government had to find additional land to compensate these displaced people, often moving them to entirely new counties or regions. ${ }^{59}$ Many have argued that human rights and rights to property were blurred throughout the processes. The options of these displaced people are limited and the preparedness of host communities is lacking, causing social conflict. Today, it is unclear how these people have faired since displacement. $^{60}$

It is obvious that the Dam has much more political importance than simply providing economic returns. It was originally envisioned as a symbol of Chinese industrialization and modernization. Such perspectives can be traced through the century from Sun Yat-sen to Mao to Xioping and Li Peng, who all saw such a dam as the ultimate achievement in China's development, whether it be a beacon of modernization, revolution, or economic growth. In addition to this, Mao instilled in Chinese Communism a feeling of mastery and control over nature. Such theories saw people and the state as separate from nature, with the ability to manipulate natural forces for their own benefit. These views were not limited to China, but the rapid level of industrialization undertaken by Communist China through campaigns such as The Great Leap Forward exacerbated environmental degradation to the point that it caused famine and death on a large scale. Today, the Dam has displaced millions of people and continues to cause untold amounts of environmental degradation. ${ }^{61}$ The idea that humans should control nature is still evident throughout the world today. However, rather than simply being a sign of modernization, the manipulation of resources is also

58 Xibao Xu, Yan Tan, and Guishan Yang, "Environmental impact assessments of the Three Gorges Project in China: Issues and interventions," Earth-Science Reviews 124, (2013): 115.

59 Ibid.,

60 Yan Tan, Resettlement in the Three Gorges Project (Hong Kong: Hong Kong University Press, 2008).

61 Gleick, "Three Gorges Dam Project Yangtze River, China," 141. recognized as essential to increased economic development. In this sense, the Three Gorges Dam is seen as a strategic asset as well as a symbolic achievement. Beyond the context of China, the Three Gorges Dam is also a symbol of larger systems that value economic benefits and industrialization over a sustainable environment. When criticizing or analyzing the Three Gorges Dam, it is important to acknowledge not only the historical and societal context in which it was built, but also that it is both a Chinese problem and an international one. 


\section{Bibliography}

Bellette Lee, Yuen-Ching. "Global Capital, National Development and Transnational Environmental Activism: Conflict and the Three Gorges Dam." Journal of Contemporary Asia 43, no. 1 (2013): 102126.

Bezlova, Antoaneta. "China's Three Gorges Dam Comes of Age." Asian Times, 4 November 2009. Accessed 18 March 2014. http://www.atimes.com/atimes/China/KKo4Ado1.h tml.

Chinese Government's Official Web Portal. "Special Report: Three Gorges Project." 2012. Accessed 10 March 2014 .

http://english.gov.cn/special/sanxia_index.htm.

Fearnside, Philip M. "China's Three Gorges Dam: 'Fatal' Project or Step Towards Modernization?" World Development 16 (1988): 615-630.

Foster, John Bellamy. "The Communist Manifesto and the Environment." The Socialist Register 34 (1998): 169190.

Fu, Shui. "A Profile of Dams in China." In The River Dragon Has Come: The Three Gorges Dam and The Fate of China's Yangtze River and Its People. Edited by Dai Qing, John G. Thubodeau, and Philip B. Williams. Translated by Yi Ming, 18-24. New York: M.E. Sharpe, Inc., 1998.

Gill, William. The River of Golden Sand: The Narrative of a Journey Through China and Eastern Tibet to Burmah. London: John Murray, 1880.

Gleick, Peter H. "Three Gorges Dam Project Yangtze River, China." In The World's Water 2008-2009: The Biennial Report on Freshwater Resources. Edited by Peter H. Gleick, 139-150. Washington: Island Press, 2009 .

Harris, Stuart A. "Environmental and Land-use Changes in the Tibetan Plateau Section of the Upper Yangtze River Basin during the Last 50 Years." In Yangtze River: Geography, Pollution and Environmental Implications. Edited by Tracy Maloney and Boyce R. Hutchins, 35-64. New York: Nova Science Publishers, Inc, 2013.
Hvistendahl, Mara. "China's Three Gorges Dam: An Environmental Catastrophe?" Scientific American. 25 March 2008. Accessed 10 March 2014. http://www.scientificamerican.com/article/chinasthree-gorges-dam-disaster/.

Kahn, Joseph and Jim Yardley. "As China Roars, Pollution Reaches Deadly Extremes." The New York Times. 26 August 2007.

Marks, Robert B. China: Its Environment and History. Maryland: Rowman and Littlefield Publishers, 2012.

Marks, Robert B. "Chinese Communists and the Environment." In Radicalism, Revolution and Reform in Modern China. Edited by Catherine Lynch, Robert B. Marks and Paul G. Pickowicz, 105132. Maryland: The Rowman and Littlefield Publishing Group Inc., 2011.

Marx, Karl, and Engels, Friedrich. The Manifesto of the Communist Party. Accessed on 18 March 2014. https://www.marxists.org/archive/marx/works/184 8/communist-manifesto/.

Meisner, Maurice. Mao's China and After: A History of the People's Republic. New York: The Free Press, 1999.

Morgan, Kepa, and Amaria Francis Waretini. "The Yangtze River: Hydro Development, Changing Geography, Cultural and Environmental Implications." In Yangtze River: Geography, Pollution and Environmental Implications. Edited by Tracy Maloney and Boyce R. Hutchins, 65-88. New York: Nova Science Publishers, Inc, 2013.

Murphy, Rhoads. "Man and Nature in China." Modern Asian Studies 1 (1967): 313-333.

Ponseti, Marta, and Jordi Lopez-Pujol. "The Three Gorges Dam Project in China: History and Consequences." Revista HMiC: Historia Moderna I Contemporania 4 (2006): 151-188.

Qing, Dai. Yangtze!Yangtze! Edited by Patricia Adams and John Thibodeau. Translated by Nancy Liu et al. London: Probe International Earthscan, 1994. Accessed 18 March 2014. http://journal.probeinternational.org/threegorges-probe/yangtze-yangtze/. 
- "The Three Gorges Project." In The River Dragon Has Come: The Three Gorges Dam and The Fate of China's Yangtze River and Its People. Edited by Dai Qing, John G. Thubodeau and Philip B. Williams. Translated by Yi Ming, 3-17. New York: M.E. Sharpe, Inc., 1998.

Schneider, Laurence. Biology and Revolution in TwentiethCentury China. Maryland: Rowman and Littlefield, 2003.

Schurmann, Franz. Ideology and Organization in Communist China. California: University of California Press, 1966.

Shapiro, Judith. Mao's War Against Nature: Politics and the Environment in Revolutionary China. United Kingdom: Cambridge University Press, 2001.

Sullivan, Lawrence B. "The Three Gorges Dam and the Chinese Polity," preface to Yangtze!Yangtze by Dai Qing, xiv-xx. Edited by Patricia Adams and John Thibodeau. Translated by Nancy Liu et al. London: Probe International Earthscan, 1994. Accessed 18 March 2014, http://journal.probeinternational.org/threegorges-probe/yangtze-yangtze/.

Tan, Yan. Resettlement in the Three Gorges Project. Hong Kong: Hong Kong University Press, 2008.

Up the Yangtze. National Film Board of Canada. Montreal: Eyesteel Film, 2007, Accessed 10 March 2014. http://putlocker.bz/watch-up-the-yangtze-onlinefree-putlocker.html.

Xu, Xibao, Yan Tan, and Guishan Yang. "Environmental impact assessments of the Three Gorges Project in China: Issues and interventions." Earth-Science Reviews 124, (2013): 115-125.

Yat-sen, Sun. The International Development of China. Shanghai: Commercial Press Limited, 1922.

Zedong, Mao. Swimming. June 1956. Retrieved from "Selected Works of Mao Tse-tung." Accessed 18 March 2014. http://www.marxists.org/reference/archive/mao/se lectedworks/poems/poems23.htm. 
